\title{
PENILAIAN KINERJA KARYAWAN DI PT.XYZ DENGAN PENDEKATAN MULTI ATTRIBUTE DECISION MAKING (MADM)
}

\author{
Dian Eko Hari Purnomo ${ }^{1}$, Risang Pujianto ${ }^{2}$ \\ 1,2) Program Studi Teknologi Pengolahan Karet dan Plastik, Politeknik ATK Yogyakarta \\ Email: dian.eko.hari.p@gmail.com, risang.pujiyanto@gmail.com
}

\begin{abstract}
ABSTRAK
Salah satu komponen penting dalam suatu proses produksi adalah karyawan. Industri yang maju dengan pesat tidak lain dan tidak bukan berkat adanya kinerja yang baik dari setiap elemen yang ada dalam suatu industri tersebut. Salah satu contoh kinerja dari karyawan yang baik akan berakibat baik pula bagi suatu perusahaan. Kinerja karyawan bagi PT. XYZ merupakan suatu elemen yang penting bagi perusahaan, karena dengan adanya karywan PT. XYZ dapat melakukan proses proses produksi. Saat ini, di perusahaan dalam melakukan penilaian kinerja karyawan masih mengalami kesulitan. Kesulitan terebut terjadi karena belum adanya kriteria yang secara rinci dapat dipergunakan untuk penilaian kinerja karyawan. Sehingga pada penelitian ini akan berusahaan menemukan kriteria-kriteria yang berpengaruh dalam penilaian kinerja karyawan. Pengolahan data pada penelitian ini menggunakan metode Weighted Prodct (WP). Selain itu, model yang telah dibuat akan diimplementasikan menjadi suatu Sistem Pendukung Keputusan (SPK). Kriteria yang dapat mempengeruhi kinerja karyawan adalah kedisiplinan, tanggung jawab, ketrampilan, dan komunilasi. Di samping itu, berdasarkan hasil pengujian Sistem Pendukung Keputusan (SPK) yang telah dibuat diperoleh kesimpulan bahwa sistem yang telah dibuat dapat dipergunakan nantinya oleh PT. XYZ untuk melakukan penilaian kinerja karyawan khususnya pada bagian produksi.
\end{abstract}

Kata kunci: Penilaian Kinerja Karyawan, Produksi, WP dan MADM

\section{Pendahuluan}

Dalam suatu kegiatan mengubah bahan baku menjadi produk tentunya melibatkan berbagai macam komponen, salah satunya adalah karyawan. Kinerja karyawan merupakan suatu hal yang penting bagi perusahaan dalam mencapai tujuan [9]. Selain itu, kemajuan sistem informasi saat ini sangatlah cepat, hal ini menuntut setiap pelaku industri melakukan penerapan teknologi informasi untuk dapat meningkatkan efisiensi perusahaan [3]. PT. XYZ merupakan suatu perusahaan manufaktur yang memproduksi kertas karton. Permintaan yang terus meningkat mengakibatkan sistem produksi perusahaan harus ditingkatkan untuk memenuhi permintaan tersebut. Untuk itu perusahaan akan memberikan penghargaan kepada karyawan bagian produksi yang mempunyai kinerja terbaik dan memberikan teguran kepada karyawan yang kurang kinerjanya. Permasalahan mulai muncul ketika perusahaan akan melakukan penilaian kinerja karyawam. Hal ini, terjadi karena pihak perusahaan belum mempunyai kriteria-kriteria yang dapat digunakan untuk menilai kinerja karyawan. Dapat dikatakan penilaian kinerja karyawan adalah salah satu aktivitas penting pada bagian untuk mencapai keunggulan bersaing [1]. Selain itu, pihak perusahaan belum menggunakan suatu metode tertentu untuk melakukan penilaian kinerja karyawan. Penilaian kinerja karyawan adalah permasalahan yang dapat didekati dengan multi kriteria dimana setiap kriteria yang digunakan mempunyai kepentingan atau informasi yang berbeda untuk setiap alternatifnya. Tujuan dari penelitian ini adalah mengidentifikasi kriteria-kriteria yang dapat digunakan dalam penilaian kinerja karyawan. Selain itu, akan dibuat suatu Sistem Pendukung Keputusan (SPK) yang dapat digunakan untuk penilaian kinerja karyawan pada bagian produksi di PT. XYZ.

Penelitian ini berbeda dengan penelitian yang lain hal ini dikarena penggunaan metode Weighted Prodct (WP) pada penelitian sebelumnya digunakan untuk penentuan strategi perusahaan [12]. Selain itu, dalam melakukan perancangan suatu perangkat lunak dapat diukur atau dapat ditinjau dari beberapa hal diantaranya adalah kemudahan dalam menggunakan [8]. Hal ini menunjukkan bahwa dalam melakukan perancangan suatu perangkat lunak tidak hanya fungsi yang sesuai dengan studi kasus akan tetapi juga kemudahan bagi pengunanya. Penelitian lain yang mempunyai tujuan untuk malakukan pengambilan keputusan juga telah dilakukan dalam hal pemilihan pemasok [7]. Pemilihan pemasok dan penilaian kinerja karyawan mempunyai kesamaan dalam kasus yang tergolong MultiAttribute Decision Making (MADM). Kasus penilain atau pengukuran kinerja karyawan memang memerlukan suatu metode dalam pengukurannya, hal ini bertujuan untuk mendapatkan penilaian kinerja yang sesuai dengan kondisi nyata. Penilian sesuai dengan kondisi nyata memang sulit dilakukan hal ini terjadi karena belum adanya model baku 


\section{KAIZEN : MANAGEMENT SYSTEMS \& INDUSTRIAL ENGINEERING JOURNAL VOL. 1 NO. 1 TEKNIK INDUSTRI UNIVERSITAS PGRI MADIUN}

dalam melakukan penilaian kinerja karyawan, sehingga penelitian ini memang perlu dilakukan mengingat tidak adanya kriteria yang baku yang dapat digunakan untuk menilai kinerja karyawan.

\section{Metode Penelitian}

Pengembangan Sistem Pendukung Keputusan (SPK) untuk menentukan penilaian kinerja karyawan mengacu kepada tahapan penelitian menggunakan pendekatan sistem sebagai berikut:

1. Mempelajari sistem produksi yang ada di perusahaan. Wawancara dan observasi untuk mendapatkan variablevariable keputusan penting dalam penilaian kinerja karyawan.

2. Mengidentifikasi kriteria-kriteria yang dapat digunakan untuk penilaian kinerja karyawan.

3. Desain sistem untuk merancang model pengambilan keputusan, basis data dan user interface pada sistem pendukung keputusan.

4. Verifikasi model menggunakan data dari PT. XYZ sebagai studi kasus.

\section{Hasil dan Pembahasan}

\section{Kegiatan Proses Produksi}

Proses produksi karton di PT. XYZ adalah karyawan bagian produksi bersiap pada bagian masing-masing. Proses pertama adalah melakukan pencampuran material untuk membentuk bubur kertas. Bubur kertas yang sudah dirasa siap, maka selanjutnya akan dilakukan proses pencetakan bubur kertas menjadi lembaran kertas karton yang panjang. Kertas karton yang panjang akan dipotong berdasarkan ukuran. Setelah proses pemotongan langkah selanjutnya adalah proses klasifikasi jenis kertas karton berdasarkan ukuran dan ketebalan kertas karton yang sudah diproduksi. Setelah proses klasifikasi, maka langkah selanjutnya adalah proses pengemasan kertas karton dengan jumlah tersentu sesuain ukuran. Setelah dikemas, maka langkdah atau proses selanjutnya adalah proses distribusi untuk setiap konsumen.

\section{Daftar Kriteria Yang Dapat Digunakan Untuk Penilaian Kinerja Karyawan}

Berikut ini adalah daftar kriteria yang dapat digunakan untuk penilaian kinerja karyawan, kriteria di bawah ini didasarkan pada penelitian terdahulu. Penentuan kriteria ini sangatlah berbeda dengan penelitian yang lain, hal ini dikarenakan kriteria dalam penelitian ini diambil dari beberapa penelitian sebelumnya. Dalam melakukan penilai karywan diperlukan kriteria kedisiplinan. Penggunaan kriteria kedisiplinan dalam melakukan penilaian kinerja karyawan ditinjau dari semakin disiplin seorang karyawan, maka akan semakin tinggi nilai kinerja karyawan tersebut [6]. Kriteria lain yang digunakan dalam penelitian ini adalah kiteria tanggung jawab. Penggunaan kriteria tanggung jawab dalam melakukan penilaian kinerja karyawan ditinjau dari semakin bertanggung jawab seorang karyawan terhadap pekerjaanya, maka semakin nilai kinerja kaaryawan tersebut [2]. Kriteria lain yang digunakan dalam penelitian ini adalah ketrampilan. Semakin tinggi ketrampilan karyawan dalam menyelesaikan pekerjaan, maka akan semakin tinggi nilai kinerja karyawan [10]. Kriteria lain yang digunakan dalam penelitian ini adalah kemampuan komunikasi karyawan. Kemampuan komunikasi karyawan akan berpengaruh terhadap penilaian kinerja karyawan.

Semakin tinggi kemampuan seorang karyawan dalam berkomunikasi, maka akan semakin tinggi pula nilai kinerja karyawan tersebut [5]. Penggunaan kriteria dalam penelitian ini diambil dari beberapa penelitian terdahulu yang kemudian dilakukan dilakukan analisis dan penentuan termasuk kedalam kriteria positif atau termasuk dalam kriteria negatif [12]. Penjelasan dari kriteria positif adalah semakin tinggi nilai karyawan pada kriteria tertentu, maka akan semakin dipilih atau semakin baik. Sedangkan penjelasan dari kriteria negatif adalah semakin rendah nilai karyawan pada kriteria tertentu, makan akan semakin tidak dipilih atau semakin kurang baik. Sehingga dalam penelitian ini ditemukan formulasi kriteria yang dapat digunakan untuk penilian kinerja karyawan. Setelah diketahui jenis kriteria maka langkah selanjutnya adalah menentukan bobot kriteria untuk masing-masing kriteria yang digunakan dalam penilaian kinerja karyawan [12]. Dalam melakukan penentuan bobot kriteria pihak perusahaan dilibatkan untuk mengatahui tingkat kepentiangan dari masing-masing kriteria. Sehingga diperoleh beberapa ringkasan hasi penelitian seperti pada Tabel 1 berikut ini: 


\section{KAIZEN : MANAGEMENT SYSTEMS \& INDUSTRIAL ENGINEERING JOURNAL VOL. 1 NO. 1 TEKNIK INDUSTRI UNIVERSITAS PGRI MADIUN}

Tabel 1. Daftar Kriteria Berdasarkan Konsultasi dengan PT. XYZ

\begin{tabular}{|c|c|c|l|c|c|}
\hline No. & Kode & Kriteria & \multicolumn{1}{|c|}{ Penjelasan } & Jenis Kriteria & Bobot \\
\hline 1 & K1 & Kedisiplinan & $\begin{array}{l}\text { Semakin disiplin seorang karyawan } \\
\text { bagian produksi maka semakin baik }\end{array}$ & Keuntungan (+) & 5 \\
\hline 2 & K2 & Tanggung Jawab & $\begin{array}{l}\text { Semakin tinggi rasa tanggung jawab } \\
\text { seorang karyawan bagian produksi } \\
\text { maka semakin baik }\end{array}$ & Keuntungan (+) & 5 \\
\hline 3 & K3 & Ketrampilan & $\begin{array}{l}\text { Semakin tinggi ketrampilan seorang } \\
\text { karyawan bagian produksi maka } \\
\text { semakin baik Keuntungan (+) }\end{array}$ & 3 \\
\hline 4 & K4 & Komunikasi & $\begin{array}{l}\text { Semakin tinggi kemampuan } \\
\text { komunikasi seorang karyawan bagian } \\
\text { produksi maka semakin baik }\end{array}$ & Keuntungan (+) & 1 \\
\hline
\end{tabular}

\section{Daftar Karyawan Bagian Produksi}

Di bawah ini adalah rincian daftar karyawan yang akan dinilai kinerjanya berdasarkan hasil pengumpulan data dari PT. XYZ, seperti terlihat pada Tabel 2.

Tabel 2. Daftar Karyawan yang Akan Dinilai

\begin{tabular}{|c|c|c|}
\hline No & Kode & Nama Karyawan \\
\hline 1 & A1 & Karyawan 1 \\
\hline 2 & A2 & Karyawan 2 \\
\hline 3 & A3 & Karyawan 3 \\
\hline
\end{tabular}

\begin{tabular}{|c|c|c|}
\hline No & Kode & Nama Karyawan \\
\hline 4 & A4 & Karyawan 4 \\
\hline 5 & A5 & Karyawan 5 \\
\hline
\end{tabular}

Struktur Hirarki dari Peniliaian Kinerja Karyawan

Dari dua bagian sebelumnya dibuat suatu struktur hirarki dari penilaian kinerja karyawan. Gambar struktur hirarkinya dapat dilihat pada Gambar 1.

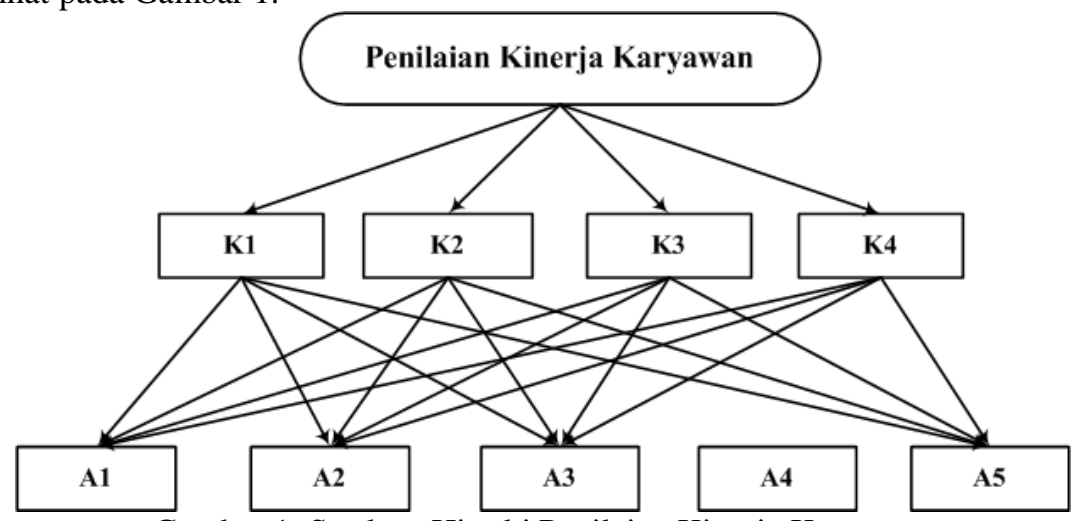

Gambar 1. Struktur Hirarki Penilaian Kinerja Karyawan

\section{Pengolahan Data Penilian Kinerja Karyawan}

Dalam kasus penilaian kinerja karyawan. Data diperoleh dari perusahaan dan pakar yang telah terbiasa melakukan penilaian kinerja karyawan. Tabel 3 adalah ringkasan hasil perhitungan dari masingmasing metode.

Tabel 3. Matriks Awal Untuk Metode Penyelesaian WP

\begin{tabular}{|c|c|c|c|c|}
\hline Alternatif & K1 & K2 & K3 & K4 \\
\hline Bobot & 0,35714 & 0,35714 & 0,21429 & 0,07143 \\
\hline Karyawan 1 (A1) & 3 & 1 & 4 & 5 \\
\hline Karyawan 2 (A2) & 1 & 3 & 3 & 3 \\
\hline Karyawan 3 (A3) & 3 & 1 & 2 & 2 \\
\hline Karyawan 5 (A5) & 1 & 5 & 2 & 4 \\
\hline Karyawan 4 (A4) & 3 & 3 & 1 & 2 \\
\hline
\end{tabular}

Copyright (C) 2018, Kaizen : Management Systems \& Industrial Engineering Journal ISSN 15222-96806 (print), ISSN $155222-95973$ (online) 
KAIZEN : MANAGEMENT SYSTEMS \& INDUSTRIAL ENGINEERING JOURNAL VOL. 1 NO. 1 TEKNIK INDUSTRI UNIVERSITAS PGRI MADIUN

Tabel 4. Matriks Awal Untuk Metode Penyelesaian WP

\begin{tabular}{|c|c|c|c|c|c|}
\hline Alternatif & K1 & K2 & K3 & K4 & Nilai WP \\
\hline Karyawan 1 (A1) & 1,48047 & 1,00000 & 1,34590 & 1,12183 & 2,23532 \\
\hline Karyawan 2 (A2) & 1,00000 & 1,48047 & 1,26544 & 1,08163 & 2,02638 \\
\hline Karyawan 3 (A3) & 1,48047 & 1,00000 & 1,16013 & 1,05076 & 1,80472 \\
\hline Karyawan 5 (A5) & 1,00000 & 1,77677 & 1,16013 & 1,10409 & 2,27585 \\
\hline Karyawan 4 (A4) & 1,48047 & 1,48047 & 1,00000 & 1,05076 & 2,30305 \\
\hline
\end{tabular}

Tabel 5. Hasil Akhir Metode Penyelesaian WP

\begin{tabular}{|c|c|c|c|}
\hline Alternatif & Total & Persentase & Ranking \\
\hline Adi & 2,23532 & $20,998 \%$ & 3 \\
\hline Yatno & 2,02638 & $19,035 \%$ & 4 \\
\hline Anam & 1,80472 & $16,953 \%$ & 5 \\
\hline Didit & 2,27585 & $21,379 \%$ & 1 \\
\hline Turyono & 2,30305 & $21,634 \%$ & \multicolumn{1}{|c}{} \\
\hline Total & 10,64531 & $100 \%$ & \\
\cline { 1 - 3 } & &
\end{tabular}

\section{Simpulan}

Berdasarkan kasus yang telah diteliti, diperoleh kesimpulan bahwa dari hasil peritungan di atas karyawan yang terbaik adalah Karyawan 5, karena mempunyai nilai persentase tertinggi berdasarkan metode WP. Pendekatan Multi Attribute Decision Making (MADM) dengan menggunakan metode WP ternyata dapat digunakan untuk penilaian kinerja karyawan.

\section{Daftar Pustaka}

[1] Amid, A., Ghodsypour, S. H., and O’Brien, C. A., Weighted Max-Min Model for Fuzzy Multi-Objective Supplier Selection in a Supply Chain, International Journal Production Economics, 2011.

[2] Antonio, A.M., Juan, M., Arjona, F., Heesup, H., and Rob L., Employee responsibility and Basic Human Values in the hospitality sector, International Journal of Hospitality Management, 62, 2017, 78-87.

[3] Kadir, A., Pengenalan Sistem Informasi, Penerbit Andi Offset, Yogyakarta, 2002.

[4] Kusumadewi, S., Hartati, S., Harjoko, A. and Wardoyo, R., Fuzzy Multi-Attribute Decision Making (FUZZY MADM), Penerbit Graha Ilmu, Yogyakarta, 2006.

[5] Jacobs, M.A., Yu, W., and Chavez, R., The Effect of Internal Communication and Employee Satisfaction on Supply Chain Integration, International Journal of Production Economics, 171(1), 2016, 60-70.

[6] Mangkunegara, A.P., and Waris, A., Effect of Training, Competence and Discipline on Employee Performance in Company, Social and Behavioral Sciences, 211, 2010, 1240-1251.

[7] Ng, Wang. L., An Efficient and Simple Model for Multiple Criteria Supplier Selection Problem, European Journal of Operational Research, 2008.

[8] Pressman, R., Software Engineering a Practitioner's Approach, McGraw-Hill Inc, Singapore, 1992.

[9] Sadikoglu, E., and Zehir, C., Investigating The Effect of Innovation and Performance on Relationship Between Total Quality Management Practices and Firm Performance: An Empirical Study of Turkish Firms, International Journal of Production Economics, 127(1), 2010, 13-26.

[10] Silva, H.C., and Lima, F., Technology, Employment and Skills: A Look Into Job Duration, Research Policy, 46(8), 2017, 1519-1530.

[11] Turban, Efraim., Aronson, J.E., and Liang, T.P., Decision Support Systems and Intelligent Systems $7^{\text {th }}$ Edition, Prentice Hall, New Delhi, 2007.

[12] Wang, M., Liu, S., Wang, S., Lai, K. K., A Weighted Product Method For Bidding Strategies In Multi Attribute Auctions, Syst Sci Complex, Berlin, 2010.

Copyright (C) 2018, Kaizen : Management Systems \& Industrial Engineering Journal ISSN 15222-96806 (print), ISSN 155222-95973 (online) 